\title{
"Clear and Convincing" Libel: Fiction and the Law of Defamation
}

In New York Times Co. v. Sullivan, ${ }^{1}$ the Supreme Court announced that the First Amendment qualifies and restricts the common law of libel. The Court's decisions since Sullivan have refined and limited the holding in that case ${ }^{2}$ but have generally been marked by both a special solicitude for free speech values and a recognition that the First Amendment requires more "breathing space" for defamatory falsehoods than the common law provides. ${ }^{3}$ But because Sullivan and its progeny have involved situations in which the news media have proffered as true something that is false, these cases and the standards they enunciate are mostly inapplicable to works of fiction, which do not purport to be, and are acknowledged by their creators not to be, factually true.

Because the news media seldom leave unclear to whom they refer, one of the two constitutional bases for the holding in Sullivan has gone largely unnoticed. The evidence in that case was deemed constitutionally defective because it could not support a finding against the newspaper that the allegedly libelous statements were made "of and concerning" the plaintiff." The "of and concerning" requirement-the demand that a defamatory statement be in some sense "about" the plaintiff-is part of the common law of libel ${ }^{\mathrm{s}}$ and is likely to be central to any defamation case involving

1. 376 U.S. $254,279-80$ (1964) (holding that public official seeking to recover damages for libel must prove "actual malice"- that defamatory falsehood was stated with knowledge of falsity or reckless disregard of truth).

2. See Wolston v. Reader's Digest Ass'n, Inc., 443 U.S. 157 (1979) (plaintiff is private figure because he had not "voluntarily thrust" himself into controversy); Hutchinson v. Proxmire, 443 U.S. 111 (1979) (plaintiff is private figure because he did not thrust himself or his views into public controversy); Time, Inc. v. Firestone, 424 U.S. 448 (1976) (finding plaintiff not public figure because she had not voluntarily put herself in forefront of public controversy); Gertz v. Robert Welch, Inc., 418 U.S. 323 (1974) (rejecting Rosenbloom v. Metromedia, Inc., 403 U.S. 29 (1971) and holding that "public figure" is determined by role in "forefront of particular public controversies" and that private person may recover without meeting Sullivan standard); Rosenbloom v. Metromedia, Inc., 403 U.S. 29 (1971) (plurality opinion) (criterion not whether plaintiff is "public figure" but whether subject of statement is matter "of public or general interest"); St. Amant v. Thompson, 390 U.S. 727 (1968) (holding that "actual malice" involves showing that defendant entertained serious doubts as to truth of his statements); Curtis Publishing Co. v. Butts, 388 U.S. 130 (1967) (extending Sullivan rule to "public figures," who do not hold government positions but are important in society); Rosenblatt v. Baer, 383 U.S. 75 (1966) (defining "public official" as person whose position invites public scrutiny and discussion).

3. New York Times Co. v. Sullivan, 376 U.S. 254, 271-72 (1964) ("erroneous statement is inevitable in free debate, and . . . must be protected if the freedoms of expression are to have the "breathing space' that they 'need . . . to survive" ") (quoting NAACP v. Button, 371 U.S. 415, 433 (1963)). 4. 376 U.S. at 288 .

5. See, e.g., Smith v. Huntington Publishing Co., 410 F. Supp. 1270, 1273 (S.D. Ohio 1975) (test is whether reasonable person could believe that article referred to plaintiff), affd, $535 \mathrm{~F} .2 \mathrm{~d} 1255$ (Gth Cir. 1976); Hanson v. Globe Newspaper Co., 159 Mass. 293, 295, 34 N.E. 462, 463 (1893) (plaintiff 
fiction. Once a plaintiff proves his identity with a fictional character, actual falsity and the awareness thereof required by Sullivan probably will follow readily from a statement's fictional context.

This Note suggests that there are circumstances under which works of fiction can be libelous, and that development of the "of and concerning" requirement both helps identify such circumstances and extends to fiction the protection it deserves, while still vindicating the libel plaintiff's interest in reputation. The Note accordingly proposes three criteria by which to judge the evidence presented to prove the "of and concerning" requirement. Such evidence first of all should show unmistakability: The statement in question must refer to the plaintiff and to no one else. Second, it should show individuality: The statement must refer specifically and personally to the plaintiff, rather than to a broad group or general undertaking. These requirements together assure clarity of reference to the plaintiff. Finally, the evidence should indicate that the statement could prompt conviction in the reader: The allegedly defamatory description must inspire the belief of its audience before it can create legally compensable damage to reputation. Only when a work of fiction meets all these criteria, as well as the other standards of the law of defamation, should a plaintiff be permitted to recover for libel.

\section{The Present Law of Libel}

Beginning with New York Times Co. v. Sullivan, the Supreme Court has fashioned a constitutional law of libel that centers on a defendant's awareness of the truth or falsity of what he writes or publishes. In Bindrim v. Mitchell, ${ }^{6}$ the California Court of Appeals applied the Sullivan "actual malice" rule to works of fiction. An analysis of Bindrim indicates why a literal application of the Sullivan standard to fiction is undesirable.

\section{A. Constitutional Standards}

New York Times Co. v. Sullivan, the first case to apply the First Amendment to libel law, relaxed the limitations imposed by the common law of libel on free expression. A unanimous Supreme Court found that "the central meaning of the First Amendment" resided in the "profound national commitment to the principle that debate on public issues should be uninhibited, robust and wide-open." Because "erroneous statement is inevitable in free debate," truth will not suffice as the sole defense for

must show defendant meant to refer to him); Coats v. News Corp., 355 Mo. 778, 783, 197 S.W.2d 958, 961 (1946) (plaintiff must establish reasonableness of belief that reference is to him).

6. 92 Cal. App. 3d 61, 155 Cal. Rptr. 29, cert. denied, 444 U.S. 984 (1979).

7. 376 U.S. at 270 . 
those who make allegedly libelous statements about public officials. ${ }^{8}$ Rather, such officials can recover damages only if a false defamatory statement is made with " 'actual malice'-that is, with knowledge that it was false or with reckless disregard of whether it was false or not." "The Court subsequently extended the Sullivan actual malice rule to "public figures"10 and has struggled to define the circumstances under which a plaintiff can be deemed to be a public figure. ${ }^{11}$

The Court addressed the issue of libel against private persons in Gertz v. Robert Welch, Inc. ${ }^{12}$ Private persons, the Court reasoned, are "more vulnerable to injury" than public figures, who "usually enjoy significantly greater access to the channels of effective communication and hence have a more realistic opportunity to counteract false statements than private individuals normally enjoy."13 More importantly, private individuals are "more deserving of recovery" than either public officials or public figures, who "have voluntarily exposed themselves to increased risk of injury from defamatory falsehood concerning them." 14 These considerations strengthen the legitimate state interest in compensating private individuals for the harm inflicted by libel. ${ }^{15}$ The Court, however, wished also to shield "the press and broadcast media from the rigors of strict liability for defamation."16 Gertz consequently permits the states to define their own standards of liability in libel suits brought by private persons "so long as they do not impose liability without fault."17 State courts following Gertz have generally chosen to adopt a fault standard based on an author's duty reasonably to ascertain the truth of his defamatory allegations. ${ }^{18}$

\footnotetext{
8. Id. at 271 .

9. Id. at 280.

10. Curtis Publishing Co. v. Butts, 388 U.S. 130 (1967).

11. See supra note 2 .

12. 418 U.S. 323 (1974).

13. Id. at 344 .

14. Id. at 345 .

15. Gertz may also have important implications for "false-light" cases involving the right of privacy. Whereas plaintiffs in libel cases sue for damage to reputation, "false-light" plaintiffs allege what might be called embarrassment, stemming from simple inaccuracy, not necessarily defamatory, in a report that deals with them. See Time, Inc. v. Hill, 385 U.S. 374, 388 (1967) (holding that magazine not liable for "false reports of matters of public interest" involving individual's private life, unless actual malice established). It is unclear whether Hill survives the Gertz public-private distinction: In Cantrell v. Forest City Publishing Co., 419 U.S. 245 (1974), the Court found actual malice and thus declined to reach the issue of whether states might apply a more relaxed standard when the false-light plaintiff is a private person. For a persuasive argument that the Sullivan rule has no place in a falselight case, see Nimmer, The Right to Speak from Times to Time: First Amendment Theory Applied to Libel and Misapplied to Privacy, 56 CALIF. L. REV. 935 (1968). Under present law, there is no reason why a libel plaintiff embarrassed by a work of fiction cannot sue under a false-light theory as well. There is also no reason why the proposals set forth in this Note would not apply in such a case.

16. Gertz, 418 U.S. at 348 .

17. Id. at 347 .

18. Sixteen of the twenty states that have addressed Gertz have adopted a simple negligence standard. Some have elaborated an explicit duty to investigate. See Peagler v. Phoenix Newspapers, Inc.,
} 


\section{B. Libel Law Applied to Fiction: Bindrim v. Mitchell}

The libel cases decided by the Supreme Court since Sullivan have usually arisen when the news media, whose audience expects factual truth, have inaccurately depicted the plaintiff. The well-publicized case of Bindrim v. Mitchell ${ }^{10}$ demonstrates the result of a scrupulous and literal application of the evolving Sullivan standard to a work of fiction.

Gwen Davis Mitchell enrolled in the "Nude Marathon" group therapy sessions of Dr. Paul Bindrim, a clinical psychologist. She subsequently wrote and published a novel entitled Touching, in which she described the nude marathon therapy of a psychiatrist called Simon Herford. ${ }^{20}$ Herford was a "fat Santa Claus type with long white hair, white sideburns, a cherubic rosy face and rosy forearms." "21 Dr. Bindrim was clean-shaven and had short hair.

Mitchell's portrait of Herford certainly was not flattering. Bindrim sued for libel, a jury found in his favor, and the appellate court upheld the verdict. Dr. Bindrim had conceded that he was a public figure, so the court applied the Sullivan actual malice test, seeking "sufficient evidence to permit the conclusion that the defendant in fact entertained serious doubts as to the truth of [her] publication." ${ }^{22}$ The court found Mitchell's "reckless disregard" of the truth "apparent from her knowledge of the truth of what transpired at the encounter, and [its difference from] the literary portrayal of that encounter."23

Moreover, the court held that the evidence satisfied the "of and concerning" requirement of Sullivan and the common law despite the differences in name, appearance, and academic degree between Bindrim and

114 Ariz. 309, 315, 560 P.2d 1216, 1220 (1977) (test is whether defendant acted reasonably in attempting to discover truth or falsity of publication); Corbett v. Register Publishing Co., 33 Conn. Supp. 4, 8, 356 A.2d 472, 475 (Super. Ct. 1975) (standard is whether defendant failed to investigate facts properly); Memphis Publishing Co. v. Nichols, 569 S.W.2d 412, 418 (Tenn. 1978) (test is one of "reasonable care and caution in checking on the truth or falsity" of communication). Even those courts that state the standard merely in terms of whether the defendant "knew or should have known" the truth, see, e.g., Foster v. Laredo Newspapers, Inc., 541 S.W.2d 809 (Tex. 1976), cert. denied, 429 U.S. 1123 (1977); Taskett v. King Broadcasting Co., 86 Wash. 2d 439, 546 P.2d 81 (1976), seem in effect to have adopted a "reasonable investigation" standard. This is certainly the import of Gertz itself, where the Court indicates that its fault standard would protect a publisher that "took every reasonable precaution to ensure the accuracy of its assertions," 418 U.S. at 346.

19. 92 Cal. App. 3d 61, 155 Cal. Rptr. 29, cert. denied, 444 U.S. 984 (1979).

20. Id. at $69,155 \mathrm{Cal}$. Rptr. at 33. Before the therapy session, Mitchell also signed a contract with Bindrim, saying she would not "write articles, or in any manner disclose who has attended the workshop or what has transpired." Id. On the basis of this agreement, the jury made a damages award on a breach of contract claim. The trial court set aside the award and the appellate court agreed, holding that what Mitchell saw was part of her own treatment and that she was free to report on it. Id. at 76, $155 \mathrm{Cal}$. Rptr. at 41 . There is, of course, no way to tell what infuence the apparent violation of the contract in Bindrim had on the libel issue for the jury.

21. Id. at $75,155 \mathrm{Cal}$. Rptr. at 37 (quoting from novel Touching).

22. Id. at 72, 155 Cal. Rptr. at 35 (citing St. Amant v. Thompson, 390 U.S. 727, 731 (1968)).

23. Id. at 72-73, 155 Cal. Rptr. at 35. 
Herford. Plaintiff would be barred from recovery, the court said, if "no one who knew [him] could possibly identify [him] with the character in the novel." ${ }^{\text {"24 }}$ After comparing a transcript of the encounter attended by Mitchell with her fictional account of a therapy session, and after reviewing the testimony of three witnesses, who based their identifications exclusively on the way Herford practiced his therapy-a form of therapy not exclusively Bindrim's own ${ }^{25}$ - the court found "overwhelming evidence that plaintiff and 'Herford' were one."26

The court rejected the defendants' argument that labelling Touching a novel precluded belief that any of its characters represented "an actual nonfiction person," asking instead "whether a reasonable person, reading the book, would understand that the fictional character therein pictured was, in actual fact, the plaintiff acting as described." Because the answer to this question was not a categorical "no," the issue was for the jury. ${ }^{27}$ The defendants also contended that the statements at issue in the novel were not false statements of fact but, rather, opinions upon which no libel could be predicated.$^{28}$ But because "the published material purport[ed] to state actual facts concerning the characters in a novel," the court found that the statements "could be determined either as fact or opinion," and again the question was for the jury. ${ }^{29}$ The court affirmed a modified judg-

24. Id. at 75, 155 Cal. Rptr. at 37 (citing Wheeler v. Dell Publishing Co., 300 F.2d 372, 376 (7th Cir. 1962)).

25. Id. at 86, 155 Cal. Rptr. at 44 (Files, J., dissenting).

26. Id. at 76, 155 Cal. Rptr. at 38 (majority opinion).

27. Id. at 78, 155 Cal. Rptr. at 39 (citing Middlebrooks v. Curtis Publishing Co., 413 F.2d 141, 143 (4th Cir. 1969)).

28. See Gertz v. Robert Welch, Inc., 418 U.S. 323, $339-40$ (1974) ("[U]nder the First Amendment there is no such thing as a false idea. However pernicious an opinion may seem, we depend for its correction not on the conscience of judges and juries but on the competition of other ideas.").

29. Bindrim, $92 \mathrm{Cal}$. $\Lambda$ pp. $3 \mathrm{~d}$ at $77-78,155 \mathrm{Cal}$. Rptr. at 39 . It has been suggested elsewhere that the privilege available for statements of opinion be applied to works of fiction. See Silver, Libel, the 'Higher Truths' of Art, and the First Amendment, 126 U. PA. L. REV. 1065, 1086 (1978). Novels, after all, are efforts at interpretation, attempts to portray life as the author sees it. The problem with treating works of fiction as opinions is that they do not look like opinions, any more than does reportage that is equally the product of one person's mind and also susceptible to the manipulations of a clever user of language. Several classic texts on the art of fiction suggest that fiction is "dramatic": It shows things rather than tells them, and lets the reader draw his own conclusions. See F. FORD, THE ENGLISH NOVEL 128-29 (1929) ("[T]he novelist must not, by taking sides, exhibit his preferences .... He has . . . to render and not to tell."); P. LUBBOCK, THE CRAFT OF FicTION 62 (1921) ("IT]he art of fiction does not begin until the novelist thinks of his story as a matter to be shown, to be so exhibited that it will tell itself."); $c f$. J. SARTRE, WHAT IS LITERATURE? 169 (B. Frechtman trans. 1949) (novels should "exist in the manner of things, of plants, of events, and not at first like products of man"). Recent literary criticism has been highly sensitive to the mistake of identifying even a firstperson narrator with his creator; even this apparently authoritative storytelling voice has the status of a created character rather than a mere mouthpiece. See M. BEARDSLEY, AESTHETICS 240 (1958) ("TT]he speaker of a literary work cannot be identifed with the author-and therefore the character and condition of the speaker can be known by internal evidence alone."); S. CHATMAN, STORY AND DISCOURSE 147 (1978) ("That it is essential not to confuse author and narrator has become a commonplace of literary theory."); $c f$. W. BOOTH, THE RHETORIC OF FICTION 152 (1961) ("TT|he range of human types that have been dramatized as narrators is almost as great as the range of other 
ment of $\$ 50,000$ in compensatory damages and, based on the finding of actual malice, ${ }^{30} \$ 25,000$ in punitive damages. ${ }^{31}$

The opinion and result in Bindrim are in no way aberrations. The court applied the Sullivan rule literally, and thus had no difficulty in finding actual malice simply from the author's knowledge of the difference between the real events in question and her fictional account of those events. The language of the tests for the "of and concerning" requirement and for treating the claim of immunity from libel for fiction per se was drawn from earlier opinions. Nor did the denial of privilege for statements of opinion in a work of fiction and the allowance of punitive damages predicated on a finding of actual malice depart in any way from prior law. ${ }^{32}$

Yet Bindrim, despite (or perhaps because of) its typicality, is a troubling case. The plaintiff's ease in surmounting the actual malice hurdle, his facility in meeting the "of and concerning" requirement, and the court's refusal to grapple with the problems that arise when a work that makes no pretense to tell literal truth is nonetheless alleged to harm a plaintiff's reputation, all suggest both the inadequacy of the present libel law when applied to fiction and the need for development of more meaningful standards for such cases.

\section{Problems with the Present Law of Libel}

The dominance of Sullivan and its progeny in the area of libel law virtually assures that the wrong analytical tools will be employed in dealing with the relatively uncommon case of alleged defamation by a fictional work. By establishing as a criterion of libel a writer's awareness of falsity, Sullivan and the succeeding constitutional cases neglect the situation of a libel suit brought against a novelist, whose work is admittedly "false"-and known to be so by reader and author alike. At the same time, the Supreme Court has done nothing to clarify the "of and concerning" requirement of libel, which determines the identification of an ag-

fictional characters."); J. MILLER, THE FORM OF VICTORIAN FICTION 4 (1968) ("novelist plays the role of a role-player," an omniscient narrator "who can enter into the lives of other people"). There is something objective about fiction: Its quasi-dramatic aspect isolates it from its creator and deprives it of the clearly editorializing voice that characterizes what we normally think of as statements of opinion. A court asking "whether the challenged language can reasonably be read as stating a fact," Myers v. Boston Magazine Co., 380 Mass. 336, 339, 403 N.E.2d 376, 378 (1980), and examining "the statement in its totality in the context in which it was uttered or published," Information Control Corp. v. Genesis One Computer Corp., 611 F.2d 781, 784 (9th Cir. 1980), is likely, given the apparent (if illusory) objectivity of fiction, to do as the Bindrim court did and simply leave the matter to the jury.

30. See infra p. 527 (discussing "actual malice" as requirement for punitive damages).

31. Bindrim, 92 Cal. App. 3d at 81-82, $155 \mathrm{Cal}$. Rptr. at 41.

32. See supra note 29 ; infra pp. 526-27. 
grieved plaintiff with the character responsible for the defamation. This requirement, in the hands of lower courts applying the common law, has proven to be an imprecise and inconsistent test. It is badly in need of the elaboration that alone can make it meaningful to potential litigants.

\section{A. The Current Constitutional Approach}

The Supreme Court has suggested, although not in the context of libel litigation, that works of art and entertainment are entitled to First Amendment protection. ${ }^{33}$ The Court has also stated, however, that "calculated falsehood," "the lie, knowingly and deliberately published," deserves no such protection. ${ }^{34}$ The two statements seem inconsistent, for works of fiction, while not purporting to be factually true and therefore not precisely "lies," surely are calculated fabrications. Because the constitutional law of libel has evolved chiefly in cases concerning the news media and thus has dealt with statements purportedly true but actually false, the Court's pronouncements on the calculated falsehoods that arise in more typical libel cases have been misapplied to works of fiction. As a result, such works now enjoy only very limited First Amendment protection.

The precise scope of the Sullivan rule, which assists the news media by giving them a limited constitutional privilege for erroneously defamatory statements, is meaningless when applied to works of fiction. Actual malice, as the Bindrim court observed, "concentrates solely on defendants' attitude toward the truth or falsity of the material published . . . and not on malicious motives." 35 But because authors are generally in a position to know the truth or falsity of their own fictional material, a jury may-indeed, virtually must-find any allegedly defamatory work to be actually malicious.

Not only is Sullivan's supposed barrier to liability actually no barrier at all when the statements at issue are fictional; "actual malice" is also a predicate in libel suits to punitive damages. The Court has indicated that only plaintiffs who establish liability under a Sullivan standard (or one more stringent, though no more stringent standard has been adopted) can

33. See Schad v. Mt. Ephraim, 452 U.S. 61, 65 (1981) (entertainment falls "within the First Amendment guarantee"); Abood v. Detroit Bd. of Educ., 431 U.S. 209, 231 (1977) (Court has never suggested "that expression about philosophical, social, artistic, economic, literary, or ethical matters ... is not entitled to full First Amendment protection"); Joseph Burstyn, Inc. v. Wilson, 343 U.S. 495, 501-02 (1952) (movies' importance as organ of public opinion not lessened by entertainment value); Winters v. New York, 333 U.S. 507, 510 (1948) (First Amendment protects material that entertains); $c f$. Miller v. California, 413 U.S. 15, 24 (1973) (to be deemed obscene and thus subject to state regulation, work must lack "serious literary, artistic, political, or scientific value").

34. Garrison v. Louisiana, 379 U.S. 64, 75 (1964).

35. Bindrim, 92 Cal. App. 3d at 73, 155 Cal. Rptr. at 35-36; see Rosenbloom v. Metromedia, Inc., 403 U.S. 29,52 n.18 (plurality opinion) (ill will and bad motive are not elements of "actual malice"). 
recover presumed or punitive damages. ${ }^{36}$ Thus, while only some newsmedia defendants are liable for such damages, all writers and publishers of fiction are potentially liable-and rendered so by the same actual malice standard that fails to furnish them any protection during the initial determination of guilt. ${ }^{\mathbf{3 7}}$

Nor does the Gertz standard, permitting states to define liability in defamation suits by private persons "so long as they do not impose liability without fault," 38 clarify the problems arising when the law of libel confronts a work of fiction. Gertz offers little enough guidance as to what constitutes a fault standard for libel in the context of a news story; one hardly can expect it to illuminate the means of applying that standard to fiction. Courts following Gertz have generally chosen to adopt a fault standard based on an author's duty reasonably to ascertain the truth of his defamatory allegations. ${ }^{39}$ But a work of fiction does not promise literal "truth"; a novelist has nothing to investigate.

Sullivan and Gertz, of course, are not wholly inapplicable to libel cases involving fiction. They maintain the common-law requirement that the allegedly libelous statement in fact be defamatory. ${ }^{40}$ They appear to acknowledge that truth will always be a complete defense to a charge of libel. ${ }^{41}$ Most importantly, they establish standards that consider the au-

36.

[W] hold that the States may not permit recovery of presumed or punitive damages, at least when liability is not based on a showing of knowledge of falsity or reckless disregard for the truth ..... In short, the private defamation plaintiff who establishes liability under a less demanding standard than that stated by New York Times may recover only such damages as are sufficient to compensate him for actual injury.

Gertz v. Robert Welch, Inc., 418 U.S. 323, 349-50 (1974).

37. The holding in Gertz does not itself make clear whether a private libel plaintiff in a state that adopts a standard of liability for private plaintiffs less stringent than that of Sullivan can ever recover presumed or punitive damages. But subsequent state and federal decisions indicate that private plaintiffs in states with a fault standard have the option of attempting to prove actual malice in order to recover more than actual damages. See, e.g., McQuoid v. Springfield Newspapers, Inc., 502 F. Supp. 1050 (W.D. Mo. 1980) (considering issue of actual malice prior to and separate from discussion of plaintiffs public or private status); Pirre v. Printing Developments, Inc., 468 F. Supp. 1028 (S.D.N.Y.) (holding that under Connecticut law, private plaintiff may be awarded punitive damages on showing of actual malice), afTd, 614 F.2d 1290 (2d Cir. 1979); Jenoff v. Hearst Corp., 453 F. Supp. 541 (D. Md. 1978) (acknowledging possibility of private plaintiffs recovering punitive damages), affd, 644 F.2d 1044 (4th Cir. 1981); Corbett v. Register Publishing Co., 33 Conn. Supp. 4, 356 A.2d 472 (Super. Ct. 1975) (same). The breadth of actual damages for libel recognized in Time, Inc., v. Firestone, 424 U.S. 448 (1976) (allowing $\$ 100,000$ jury award for mental anguish), may make the availability of punitive or presumed damages in any given case less important.

38. Gertz v. Robert Welch, Inc., 418 U.S. 323, 347 (1974).

39. See supra note 18.

40. Defamation traditionally has been viewed as consisting of "utterances which arouse hatred, contempt, scorn and the like." See Grant v. Reader's Digest Ass'n, Inc., 151 F.2d 733, 735 (2d Cir. 1945), cert. denied, 326 U.S. 797 (1946). The Second Restatement of Torts takes a more general approach: "A communication is defamatory if it tends so to harm the reputation of another as to lower him in the estimation of the community or to deter third persons from associating or dealing with him." RESTATEMENT (SECOND) OF TORTS $\$ 559$ (1977).

41. Implicit in the Sullivan actual malice rule is the proposition that there is a constitutional right 
thor's intent and knowledge in a judgment of his liability. They thus abrogate the common-law rule that even an inadvertent or unintentional reference to a libel plaintiff is potentially libelous. ${ }^{42}$

Generally, though, while Sullivan provides a standard of liability that is all too easily applied to fiction, Gertz's minimal fault standard seems difficult to apply. The only definition of a novelist's "fault" that does not import unwelcome aesthetic criteria to a legal setting is that he has somehow failed to write "fiction": that his work, though purportedly about fictional characters, in fact refers circumstantially, credibly, and defamatorily to real people. And this definition suggests that courts should look to the "of and concerning" requirement of libel-the requirement that the allegedly libelous statements actually refer to the plaintiff-when they deal with potentially libelous works of fiction. Sullivan and Gertz are both designed to extend protection for speech beyond that provided by common law and to diminish the need for media self-censorship ${ }^{43}$ by providing rules that preclude "unpredictable results and uncertain expectations." 4 But the present law of libel concerning fiction offers defendants neither protection nor predictability and will not do so until more appropriate standards are developed.

\section{B. The "Of and Concerning" Requirement}

Satisfaction of the "of and concerning" requirement of libel often will

to speak defamatory truth. See Garrison v. Louisiana, 379 U.S. 64, 74 (1964). In Cox Broadcasting Corp. v. Cohn, 420 U.S. 469, 489-90 (1975), however, the Court in dictum leaves open the question whether truth is a constitutionally required defense to a libel action by a private plaintiff. Justice Powell's concurrence, however, argues that the defense of truth is implicit in the Gertz minimum fault standard. 420 U.S. at 498-99 (Powell, J., concurring). The dispute may have been resolved in Time, Inc. v. Firestone, 424 U.S. 448,458 (1976), where the majority observed in dictum that "demonstration that an article was true would seem to preclude finding the publisher at fault." In any event, the tendency to interpret Gertz's negligence requirement as imposing a duty reasonably to ascertain the truth of a published statement, see supra note 18, suggests that Justice Powell's view prevails.

42. See, e.g., Fetler v. Houghton Mifflin Co., 364 F.2d 650, 653 (2d Cir. 1966) (author's intent irrelevant in determining defamation); Kerby v. Hal Roach Studios, Inc., 53 Cal. App. 2d 207, 209, 127 P.2d 577, 581 (1942) (author's intent irrelevant in determining defamation); Corrigan v. BobbsMerrill Co., 228 N.Y. 58, 64, 126 N.E. 260, 262 (1920) ("[T]he question is not so much who was aimed at but who was hit."); E. Hulton v. Jones, 26 T.L.R. 128 (H.L. 1909) (question not author's intent but public's reasonable understanding of his intent).

Even before Gertz, however, some courts protected from liability authors who inadvertently referred to plaintiffs. See Hanson v. Globe Newspaper Co., 159 Mass. 293, 295, 34 N.E. 462, 463 (1893) (if writing is ambiguous, plaintiff must show defendant intended to refer to him); Landau v. CBS, 205 Misc. 357, 128 N.Y.S.2d 254 (Sup. Ct. 1954), aff'd, 1 A.D.2d 660, 147 N.Y.S.2d 687 (1955); People v. Charles Scribner's Sons, 205 Misc. 818,130 N.Y.S.2d 514 (Magis. Ct. 1954).

43. See Gertz v. Robert Welch, Inc., 418 U.S. 323, 342 (1974) (Sullivan standard "administers an extremely powerful antidote to the inducement to media self-censorship of the common-law rule of strict liability for libel and slander"). Though its negligence standard for private plaintiffs lightens the burden placed upon plaintiffs by Sullivan, Gertz itself is a "caveat against strict liability." Id. at 347 n.10.

44. Id. at 343. 
be all that is required of a plaintiff seeking recovery of damages for alleged defamation by a work of fiction. But this requirement, which generally takes the form of an unelaborated reasonable-person standard, lacks both content and consistency when applied to works of fiction. The shortcomings of the current "of and concerning" standard can lead to the same kind of "chilling effect" on writers and publishers that the Sullivan holding sought to prevent. $^{45}$

\section{Problems with the Current "Of and Concerning" Requirement}

Typical news-media libel cases, whatever their complexities, present no mystery as to whom the defamatory statements are about. Because constitutional libel jurisprudence has dealt almost exclusively with such cases, the Supreme Court's second basis for the disposition in Sullivan-that the evidence in the case was "constitutionally defective" because "incapable of supporting the jury's finding that the allegedly libelous statements were made 'of and concerning' respondent" ${ }^{\text {"16 }}$ - has gone undeveloped.

In libel cases involving fiction, however, the plaintiff's recognizability as a character in a particular work is likely to be not merely central to but dispositive of the case. Because fiction does not claim to be factually true, the constitutional requirement of actual malice probably will be easily satisfied. A plaintiff sufficiently aroused to initiate what may be a long and costly litigation can probably show that the statements at issue are false. Only the "of and concerning" requirement will stand between him and recovery.

But the outlines of this last requirement are hazy. The Supreme Court declined to hear Bindrim v. Mitchell, ${ }^{\mathbf{7}}$ and libel cases involving fiction are relatively rare. The development of the "of and concerning" requirement has been left entirely to lower courts applying the common law. Most courts use some variation of a reasonable-person standard when applying the "of and concerning" requirement: If a reasonable person could reasonably believe that the character in question refers to the plaintiff, the requirement is satisfied. ${ }^{48}$ The test seems unobjectionable in principle, but

45. See New York Times Co. v. Sullivan, 376 U.S. 254, 279 (1964) (rule compelling would-be critics of official conduct to guarantee truth of factual assertions might deter them "from voicing their criticism, even though it is believed to be true and even though it is in fact true, because of doubt whether it can be proved in court or fear of the expense of having to do so").

46. Id. at 288 .

47. 92 Cal. App. 3d 61, 155 Cal. Rptr. 29, cert. denied, 444 U.S. 984 (1979).

48. See, e.g., Geisler v. Petrocelli, 616 F.2d 636, 639 (2d Cir. 1980) ("reasonable reader must rationally suspect" character is plaintiff); Middlebrooks v. Curtis Publishing Co., 413 F.2d 141, 142 (4th Cir. 1969) (standard is whether character reasonably could be understood as portrayal of plain(iff); Wheeler v. Dell Publishing Co., 300 F.2d 372, 376 (7th Cir. 1962) (whether reasonable person who knew plaintiff could reasonably identify her with character); Davis v. R.K.O. Radio Pictures, Inc., 191 F.2d 901, 904 (8th Cir. 1951) (whether character reasonably could be understood as por- 
its present vagueness leads to results so unpredictable that no author or publisher can be confident of having avoided libel.

An examination of libel decisions involving works of fiction reveals the problems with the test in its present form. Courts differ over what sorts of similarities serve to identify a plaintiff with his alleged fictional counterpart, ${ }^{48}$ and over the significance of dissimilarities between plaintiffs and characters who otherwise resemble each other. ${ }^{60}$ Nor do courts agree about the legal effects of an author's lack of intent to write "of and concerning" the plaintiff, ${ }^{\mathbf{5 1}}$ of the standard disclaimer accompanying fictional works, ${ }^{52}$ or of other indications of a work's fictitiousness. ${ }^{83}$ Finally, "fic-

trayal of plaintiff); Smith v. Huntington Publishing Co., 410 F. Supp. 1270, 1273 (S.D. Ohio 1975) (whether reasonable person could believe article referred to plaintiff), affd., 535 F.2d 1255 (6th Cir. 1976); cf. Fetler v. Houghton Miffin Co., 364 F.2d 650, 651 (2d Cir. 1966) (libel must designate plaintiff " "in such a way as to let those who knew understand he was meant'"); Bindrim v. Mitchell, 92 Cal. App. 3d 61, 78, 155 Cal. Rptr. 29, 39 (same), cert. denied, 444 U.S. 984 (1979).

49. Compare Bindrim v. Mitchell, 92 Cal. App. 3d 61, 155 Cal. Rptr. 29 (plaintiff prevailed despite differences in name and physical characteristics), cert. denied, 444 U.S. 984 (1979) and Petitioner's Brief for Certiorari at 13-15, id. ("of and concerning" requirement satisfied by testimony of three of plaintiff's friends, identifying plaintiff on the basis of similarity of his method of therapy to character's) and Geisler v. Petrocelli, 616 F.2d 636 (2d Cir. 1980) (plaintiff's averments that she and character shared only name and physical characteristics, and that she was casually acquainted with author, sufficient to withstand motion to dismiss) with Wright v. R.K.O. Pictures, 55 F. Supp. 639, 640 (D. Mass. 1944) (finding for defendant because film in question, while containing certain features that might have associated the characters portrayed with the plaintiffs, "omitted or changed a lot of details which might have served to tie up" characters with real people).

50. Compare Wheeler v. Dell Publishing Co., 300 F.2d 372, 376 (7th Cir. 1962) (sustaining summary judgment for defendant because reasonable reader "would more likely conclude that the author created [the character] in an ugly way so that none would identify her with" plaintiff) with Fetler v. Houghton Mifflin Co., 364 F.2d 650, 653 (2d Cir. 1966) (rejecting defendant's argument that "many dissimilarities" between plaintiff and character in novel "destroy any reference the less numerous similarities might create alone" and finding that dissimilarities "pose an issue of fact as to identification, making summary judgment inappropriate").

51. Compare Smith v. Huntington Publishing Co., 410 F. Supp. 1270, 1273 (S.D. Ohio 1975) (holding author's intent immaterial to "of and concerning" test), aff'd, 535 F.2d 1255 (6th Cir. 1976) with Clare v. Farrell, 70 F. Supp. 276, 280 (D.Minn. 1947) (defendant granted summary judgment because "the writer intended to portray no actual person"). See also cases cited supra note 42 (demonstrating results on "intent" question). But cf. text accompanying note 42 (suggesting Sullivan and Gertz make intent a predicate of libel).

52. Compare Fetler v. Houghton Mifflin Co., 364 F.2d 650, 653-54 (2d Cir. 1966) (holding that standard disclaimer did not affect merits of case) and Kelly v. Loew's, Inc., 76 F. Supp. 473, 485 (D. Mass. 1948) (finding film's disclaimers "disingenuous" and "tongue-in-the-cheek" and holding for plaintiff) with Hicks v. Casablanca Records, 464 F. Supp. 426, $432-433$ (S.D.N.Y. 1978) (granting dismissal of plaintiff's right-of-publicity case because "fictionalization" in question would "by the presence of the word 'novel' [on its cover]" indicate to the reader "that the work was fictitious," thus indicating "[no] attempt . . . to present the disputed events as true") and Smith v. Huntington Publishing Co., 410 F. Supp. 1270, 1273-74 (S.D. Ohio 1975) (sustaining summary judgment for defendant, despite "very similar" characteristics and identical names of plaintiff and character, and despite presentation of story as "true," because of "clear statement by the author in boldface print that the names were fictitious"), affd, 535 F.2d 1255 (6th Cir. 1976).

53. Compare Middlebrooks v. Curtis Publishing Co., 413 F.2d 141, 143 (4th Cir. 1969) (basing decision for defendant partly upon "the common understanding of fiction as fiction only") with Pring v. Penthouse Int'l, Ltd., 695 F.2d 438, 442 (10th Cir. 1982) (characterization of article as "fiction" or "humor" in magazine in which it appeared is irrelevant to libel determination), cert. denied, 51 U.S.L.W. 3897 (U.S. June 21, 1983) (No. 82-1621) and Clare v. Farrell, 70 F. Supp. 276, 277 (D. Minn. 1947) (mentioning but not finding dispositive the fact that "jacket of the book designates the 
tionalizations" of real-life events receive inconsistent judicial treatment: Some courts downplay, but others emphasize, the increased danger with such works "that the public . . . will believe that the presentation refers to the plaintiff." 34

The standards invoked by various courts for their "of and concerning" requirements yield no particular principles on which litigants can rely. Authors and publishers simply cannot tell which aspects of a portrayal will be considered significant in comparing plaintiffs and characters. They cannot tell whether a fictional description's "ugliness" serves to preclude identification or whether it constitutes false and libelous matter. They will be unsure whether even their best efforts will shield them from libel, or whether a mere disclaimer will suffice. They will be uncertain what liberties they may take with historical characters and events. And even if they are confident of prevailing, they will be unsure, in an era of enormous litigation costs, ${ }^{\mathrm{Bs}}$ of what stage in the litigation will bring them success. These same uncertainties also confront a plaintiff who believes himself libeled by a work of fiction.

\section{The Need for a More Specific "Of and Concerning" Requirement}

There appears to be a fundamental illogicality in applying the law of libel to fiction. Fiction, after all, is fictitious. A novel announces itself as factually untrue; arguably, readers know this, and neither take nor have any right to take its words as referring literally to the real world. Furthermore, quite aside from the fictitiousness of fiction, there seems to be something absurd about permitting liability for fictional works. What is similar to the plaintiff in a given work identifies him; what is dissimilar and unflattering is false and defamatory, and therefore libelous. ${ }^{58}$ At the very least, this paradox suggests a case in which a plaintiff, by relying on minor or adventitious similarities between himself and a fictional character

story as 'a major full length novel." ").

54. American Broadcasting-Paramount Theatres, Inc. v. Simpson, 106 Ga. App. 230, 243, 126 S.E.2d 873, 881 (1962). This case involved a television program portraying the escape of Al Capone from federal custody, in part through the offices of a corrupt guard. Capone's real-life guard prevailed in a libel suit, even though his name was not used, he did not physically resemble the actor portraying the corrupt guard, and the program offered a disclaimer of its truthfulness. See also Kelly v. Loew's, Inc., 76 F. Supp. 473, 477, 485 (D. Mass. 1948) (despite disclaimer, film based on book purporting to be "substantially accurate report of "historical events" "plainly asked the audience to believe" that character "was substantially like" inaccurately portrayed plaintiff). But see Hicks v. Casablanca Records, 464 F. Supp. 426, 433 (S.D.N.Y. 1978) (presence of the word "novel" on cover sufficient to insulate from right-of-publicity claim a fictionalization of incident in life of Agatha Christie).

55. On the costliness of libel litigation, see Anderson, Libel and Press Self-Censorship, 53 TEX. L. REV. 422, 424-25, 435-36 (1975).

56. Bindrim v. Mitcheil, 92 Cal. App. 3d 61, 86, 155 Cal. Rptr. 29, 44 (Files, J., dissenting), cert. denied, 444 U.S. 984 (1979). 
to satisfy the "of and concerning" requirement, might prevail upon a sympathetic judge or jury to obtain a recovery. ${ }^{37}$ In fact, one recent opinion inverts the paradox and notes "the disturbing irony inherent in the scheme: the more virtuous the victim of the libel, the less likely it will be that she will be able to establish this essential confusion [between plaintiff and character] in the mind of the third party." applied at all to fiction, it must seek a path between the two versions of this paradox. A more specific "of and concerning" requirement can define the degree of similarity and dissimilarity between plaintiffs and fictional characters needed to support a finding of liability.

In addition, despite the common understanding of the term "fiction" and the standard disclaimer of resemblance to real people and events that prefaces many fictional works, many readers seem nonetheless inclined to take fiction, or aspects of fiction, as the literal truth. Authors occasionally express their exasperation at readers' assumptions that their novels are "really" reportage or biography. ${ }^{59}$ Nor are presumably sophisticated literary critics immune to this practice: Much criticism and literary biography is devoted to locating the real-life sources of the characters in fiction. ${ }^{80}$ The plaintiff's witnesses in Bindrim understood the novel in question to be "fiction" yet testified that they identified a character in the novel as the plaintiff, ${ }^{61}$ and their testimony convinced the jury on that point. Such contradictions have led one commentator to suggest that a book "determined

57. A well-known commentary on Sullivan makes a similar (though not identical) point. The plaintiff there prevailed in the lower courts with a

technique by which defamation might be endlessly manufactured. First, it is argued that, contrary to all appearances, a statement referred to the plaintiff; then, that it falsely ascribed to the plaintiff something that he did not do, which should be rather easy to prove about a statement that did not refer to plaintiff in the first place.

Kalven, The New York Times Case: A Note on 'The Central Meaning of the First Amendment', 1964 SUP. CT. REV. 191, 199. The more important question for fiction arises not when a fictional character does not refer at all to a real person, but rather when there is some resemblance between character and plaintiff and a court must ask how much "reference" adds up to "identification."

58. Geisler v. Petrocelli, 616 F.2d 636, 639 (2d Cir. 1980).

59. See, e.g., H. JAMES, THEORY OF FICTION 204-05 (J. Miller ed. 1972) (James's mortification upon learning that an acquaintance thought herself to be source for character in his novel The Bostonians); Finkielkraut, The Ghosts of Roth, EsQuIRE, Sept. 1981, at 92, 94 ("To label books like mine 'autobiographical' . . . is not only to falsify their suppositional nature but . . . to slight the very artfulness that leads some readers to think that they must be autobiographical.") (interview with Philip Roth).

60. A list of supposed real-life prototypes of fictional characters might be multiplied almost endlessly through a reading of literary biography. See, e.g., C. BAKER, ERNEST HEMINGWAY 179 (1969) (characters in The Sun Also Rises based on real people); C. BROOKS, WILLIAM FAULKNER 384, 39192, 446 (1963) (real-life prototypes of characters in Sartoris, Sanctuary and The Reivers); L. EDEL, HENRY JAMES: THE MASTER 111-12 (1972) (prototypes of characters in The Wings of the Dove); J. MELlOW, NATHANIEL HaWTHORNE IN HIS TIMES 399-400 (1980) (real-life sources of characters in The Blithedale Romance); E. MILLER, MELVILlE 239-40 (1975) (sources for characters in Pierre); A. TURNBULL, SCOTT FITZGERALD 305-06 (1962) (source of protagonist of The Last Tycoon).

61. Petitioner's Brief for Certiorari at 14, Bindrim v. Mitchell, 92 Cal. App. 3d 61, 155 Cal. Rptr. 29, cert. denied, 444 U.S. 984 (1979). 
to be fictional" should be absolutely immune to defamation suits. ${ }^{82}$ But the contradiction seems to be one that the law must live with. If readers can both acknowledge that a work is "fictional" and still believe that it refers to a real person, then the label attached to the work should be no more dispositive than is the routine disclaimer. Only a standard more attuned to a reader's actual belief in the contents of the work can address and resolve this contradiction.

A specific "of and concerning" requirement can also provide a necessary limit to the First Amendment protection enjoyed by fiction. Authors themselves may recognize, quite independently of any legal advice they receive, the defamatory capacity of their work. The novelist-defendant in Bindrim told a witness in the case that she had painted a "devastating portrait" of the plaintiff. ${ }^{63}$ Writing a novel is clearly no small undertaking. It should not surprise us if the motives for such a project are diverse, and sometimes include hatred, malice (in the traditional sense of the term), and revenge. There is no good reason why such motives, when they result in a novel genuinely damaging to reputation, should receive any greater protection than they would have received had they led to the production of a similar work of nonfiction.

It is, moreover, an observation as old as literary criticism itself, and long predating the ascendancy of "realistic" prose fiction in Western literary culture ${ }^{64}$ that readers enjoy and value imitations of life for their own sake. ${ }^{65}$ It has been argued that the relentless circumstantiality of fiction is

62. Comment, Defamation in Fiction: The Case for Absolute First Amendment Protection, 29 AM. U.L. REV. 571, 593 (1980). The author proposes that absolute protection be provided when "a reasonable person of average literary sophistication" would label the work in question fiction. Id. As suggested above, however, this labelling is compatible with a belief that a plaintiff is identifiable with a fictional character. The requirement that a work be considered fiction seems a less effective surrogate for the more precise requirement, proposed in this Note, that it prompt in certain specific ways belief in the literal truth of its reference to a real person.

The contention that fiction is uniquely entitled to absolute First Amendment protection should be distinguished from the "true" absolutist position, associated with Justices Black and Douglas, that the First Amendment prohibits any restraint on speech. See generally Black, The Bill of Rights, 35 N.Y.U. L. REV. 865 (1960); Countryman, Justice Douglas and Freedom of Expression, 1978 U. ILL. L.F. 301. Justice Douglas foresaw some of the problems discussed in this Note and argued that a fictionalized account of a news event was "as much in the public domain as would be a water color of the assassination of a public official." Time, Inc. v. Hill, 385 U.S. 374, 401 (1967) (Douglas, J., concurring) (false-light privacy case).

63. Bindrim v. Mitchell, 91 Cal. App. 3d 61, 69, 155 Cal. Rptr. 29, 34, cert. denied, 444 U.S. 984 (1979).

64. Though no literary form lacks antecedents, and certain features of the novel can be found in the literature of antiquity, it is broadly true that the novel originated in the early 18 th century. See $\mathrm{L}$. STEVENSON, THE ENGLISH NOVEL 54-78 (1960); I. WATT, THE RISE OF THE NOVEL 9-34 (1957).

65. See ARISTOTLE, POETICS (S. Butcher trans.), in S. BUTCHER, ARISTOTLE'S THEORY OF POETRY AND FINE ART 15 (4th ed. 1951) (imitation "is one instinct of our nature"); id. at 11 ("the objects of imitation are men in action."). For Aristotle, however, "the emphasis is on actions, not on the men performing the action .... Action comes first, it is the object of imitation. The agents who perform the action come second." Hardison, A Commentary on Aristotle's Poetics, in ARISTOTLE's POETICS: A TRANSLATION AND COMMENTARY FOR STUDENTS OF LITERATURE (O. Hardison \& $\mathrm{L}$. 
as conventional as the purest romance or fantasy, a "literary genre" only.$^{66}$ But even contemporary criticism, which makes much of the arbitrariness, conventionality, and nonreferentiality of even the most "realistic" fiction, allows a place for this exclusively mimetic function of literature. $^{67}$ The fact is that people evidently value the quasi-deception that fiction practices, its illusion of reality. If fiction sometimes becomes an outright and intentional deception, capable of harm, the legal solution should not be to bemoan the lack of an enlightened readership, but to seek better principles for detecting and compensating the harm. And because the existence of the harm depends on whether readers of a work of fiction believe a character actually to be a real person, the "of and concerning" requirement seems the right area in which to seek these principles.

\section{A New Standard for Libel in Fiction}

Although realistic fiction shares many of its techniques with reportage, it makes use of "facts" in a different way. Whereas reportage endeavors to tell the literal truth, fiction aims to make a synecdochic statement: It is a "slice of life," offered less for the sake of the particular "facts" it presents than for the sake of what it represents about the human condition generally. Only when a work purportedly fictional offers an account of particular, identifiable people taking believable action is it truly indistinguishable from reportage, and only then should it be vulnerable to a charge of defamation. An "of and concerning" test that inquires into the clarity with

Golden eds. 1968). For Plato, "all poetry, from Homer onwards, consists in representing a semblance of its subject," leaving poetry "at the third remove from reality," a semblance merely. PLATO, REPUB. LIC 331,329 (F. Cornford trans. 1945).

66. Silver, supra note 29, at 1086; see also I. WATT, supra note 64, at 32 ("Formal realism is, of course, like the rules of evidence, only a convention; and there is no reason why the report on human life which is presented by it should in fact be any truer than those presented through the very different conventions of other literary genres."). The same point has been made about the characters of fiction: "The character we admire as the result of loving attention is something constructed by conventions as arbitrary as any other, and we can only hope to recover an art by recognizing it as an art." Price, The Other Self, in IMAGINED WORLDS 279, 293 (M. Mack ed. 1968).

It has been contended, however, that realism is not one genre among many but an evolutionary improvement in literature: Its introduction in the 18th century "was like the introduction of electricity into machine technology. It raised the state of the art to an entirely new magnitude." $T$. WOLFE, THE NEW JOURNALISM at xi (1974).

67. Structuralist critics reconcile the conventional and mimetic aspects of realistic fiction by suggesting that "the basic convention governing the novel is the expectation that readers will, through their contact with the text be able to recognize a world which it produces or to which it refers." J. CULLER, STRUCTURALIST POETICS 192 (1975). "In place of the novel as mimesis we have the novel as a structure which plays with different modes of ordering and enables the reader to understand how he makes sense of the world." Id. at 238. But realistic fiction nonetheless contains elements whose function it is "to assert the representational or mimetic orientation of fiction." Id. at 193. One critic, for example, isolates in a particular text five "codes," organizational categories which enable a reader to group together and treat as meaningful diverse elements in a novella by Balzac. One of these codes is "cultural" or "referential"; it "appear[s] to establish reality, "Life." " R. BARTHES, S/Z 206 (R. Howard trans. 1974). 
which a fictional portrait refers to the plaintiff and into the conviction that portrait prompts in the reader seems the best way to determine whether a work of fiction resembles a factual report sufficiently to damage a plaintiff's reputation.

\section{A. Fiction as Synecdoche}

Perhaps the chief conceptual problem in applying the law of libel to novels derives not from fiction's fictitiousness per se but from the fact that its peculiar value is due to both its "falsity" and its "truth." Because even the most rigorously naturalistic novelist is not bound by literal, historical fact, he can offer an epitome of reality, a distilled version of the world that implicitly generalizes individual experience and suggests the broad significance of particular people, things, and events. A novelist selects from the welter of experience and the realm of the possible those things he considers important and combines them to emphasize his beliefs. ${ }^{68} \mathrm{~A}$ novel, however well it sustains the illusion that it merely reports on life, is always in a sense symbolic: It offers itself as a concrete embodiment of an abstract and general truth.

But "symbolic" is in fact an inaccurate term. It suggests a one-to-one correspondence between concrete fact and abstract idea, thereby implying that fiction is always "about" ideas, that it serves as a veiled philosophical discourse. But the themes of fiction are not often readily reducible to the propositions of philosophy. ${ }^{68} \mathrm{~A}$ better term to describe fiction is "synecdochic." Synecdoche is the name for the rhetorical device whereby a part

68. The locus classicus for this notion may perhaps be found in Henry James:

In proportion as in what fiction offers us we see life without rearrangement do we feel that we are touching the truth; in proportion as we see it with rearrangement do we feel that we are being put off with a substitute . . . . Art is essentially selection, but it is a selection whose main care is to be typical, to be inclusive.

H. JAMES, THEORY OF FICTION 39 (J. Miller ed. 1972). This argument-that formal arrangement and imitative realism are fully compatible-is frequently made. See, e.g., E. KRIS, PSYCHOANALYTIC EXPLORATIONS IN ART 52 (1952) ("Every line or every stroke of the chisel is a simplification, a reduction of reality . . . . But destruction of the real is fused with construction of its image. . . ."); I. MURDOCH, THE SOVEREIGNTY OF THE GOOD 84-85 (1970) ("Good art reveals . . . the minute and absolutely random detail of the world, and reveals it together with a sense of unity and form . . . . We are presented with a truthful image of the human condition in a form which can be steadily contemplated; and indeed this is the only context in which many of us are capable of contemplating it at all.").

For other critics, the relationship between the randomness of reality and the demand that fiction be ordered and arranged is more problematic. See F. KERMODE, THE SENSE OF AN ENDING 11, 133 (1967) (discussing man's "permanent need to live by the pattern rather than the fact" and noting "difficulty in relating one's fictions to what one knows about the nature of reality").

69.

[T]he artist is not asked to construct an adequate philosophy, but a philosophically adequate world, a different matter altogether. He creates an object . . . from whose nature, as from our own world, a philosophical system may be inferred; but he does not, except by inadvertence or mistaken esthetic principle, deem it his task to philosophize.

W. GASS, FICTION AND THE FIGURES OF LIFE 9 (1972). 
is made to stand for a whole. ${ }^{70}$ And this is what fiction does: It offers a more or less narrow, more or less particular version of experience not only for its own sake but also in order to enable a reader to say, "Life's like that." Serious fiction usually asks to be taken for more than it appears literally to be: It aspires to be seen as a "slice of life," a synecdoche that reflects on reality generally by presenting one aspect of reality. ${ }^{\mathbf{7 1}}$

This synecdochic dimension of realistic fiction is what distinguishes it from, and gives it value apart from, reportage. Whether a novel offers escape from the reader's reality, initiation into a grimmer reality, or an interpretation of a world already familiar to the reader, it gestures beyond its own circumstantiality towards a more general statement about the human condition. ${ }^{72}$ Although the techniques of reportage are often the techniques of fiction as well, only the former uses facts largely for their own sake. One reads a newspaper expecting to discover what "actually happened," and one may be outraged, quite apart from any damage to reputation that results from inaccurate statements, to learn that the "truth" of an item that purports to be factual exists only at a synecdochic or symbolic level. ${ }^{73}$ Conversely, a work of fiction uses facts also for what they represent. The work is not so much "real" as "realistic": Its peculiar value derives from its ability to take the reader beyond both his own world and the apparently "factual" world of the work, to embody the general in the particular.

Fiction's use of reportorial technique in the service of synecdochic statement is what the law of libel should strive to protect. However copious and comprehensive a novelist's imagination, he is invariably bound by his

70. H. SHAW, CONCISE Dictionary OF LiTERARY TERMS 267 (1972).

71. Another way of expressing this idea is to call the novel a "model":

Whether the governing spirit is satirical or sympathetic, whether the novel's form is documentary or symbolic, the shaping of experience will move toward what might be called a model. The value of the model is that it finds a manageable scale or form . . . [I]ts end is to study the reality it represents and perhaps to manipulate it experimentally.

Price, The Fictional Contract, in LITERARY THEORY AND STRUGTURE 168 (F. Brady, J. Palmer \& M. Price eds. 1972); see also W. GASS, supra note 69, at 71 (humans are "inveterate model makers, imposing on the pure data of sense a rigorously abstract system").

72. This is not to suggest that the mimetic qualities of fiction are not pleasurable and valuable in themselves. The notion that they are is a central tenet of literary criticism from Aristotle, see supra note 65 , to the present day, see supra note 67 . It is rather to say that fiction, unlike reportage, engages in a deliberate and expected shaping of experience, a rounding off of the factually true in the name of formal and thematic coherence that would be intolerable from something readers expected to tell the literal truth.

73. Perhaps the best demonstration of this is the controversy over a newspaper article about an eight-year-old boy addicted to heroin. The author received a Pulitzer Prize for her article but subsequently was discovered to have invented the boy: He was a fictional device, a composite assembled from the reporter's notes to personify her impressions of ghetto drug addiction. The newspaper dismissed the author, returned the award, and published a lengthy apology. See Lapham, Gilding the News, HARPER's, July 1981, at 31-39. The same article, published or otherwise understood as fiction, would presumably have been unobjectionable. 
own experience in devising his work. Relatively recognizable people from his own world are likely to populate his fiction. ${ }^{74}$ But because reality does not reveal its meaning to a novelist any more readily than it does to anyone else, a writer will select, combine and condense in the service of formal and thematic coherence. An author who believes that unvarnished, unembellished experience rendered in language has its own synecdochic significance is entitled to the belief, but ought to be held to its obvious consequences: If one is merely reporting, one had better tell the literal truth to the best of one's ability.

Only when the realistic dimension of a work purportedly fictional altogether obscures its synecdochic dimension-when, that is, the work (or a part of it $)^{75}$ becomes effectively indistinguishable from reportage-should its author be vulnerable to a charge of libel. When a novel offers to its readers only what a newspaper account does-a report of particular, identifiable people taking believable action-it ceases, in effect, to be a novel, and relinquishes both its claim to tell a sort of truth inaccessible to reportage and, hence, its claim to any distinct legal protection. ${ }^{76} \mathrm{~A}$ statement that neither embodies a synecdochic truth nor renders a literal truth is simply a lie. It is, to adopt the Supreme Court's terminology, a "calculated falsehood," part of whose calculation derives from the disingenuous, ostensibly fictional context in which it is presented.

74. See H. PILPEL \& T. ZAVIN, RIGHTS AND WRITERS: A HANDBOOK OF LITERARY AND ENTERTAINMENT LAW 23 (1960) ("First novels] tend to be autobiographical, and twentieth century fiction is replete with examples of writers whose first novel, at least, leaned heavily on the author's (usually unflattering) portrayal of and judgment on his family.").

75. See infra note 86 .

76. A rule of absolute privilege seems not only undesirable, but unlikely to receive widespread support. Such a rule is unlikely to be supported partly because the recent trend of Supreme Court decisions shows an increasing concern for the individual's reputation. This concern is chiefly embodied in efforts to limit, and in fact reduce, the scope of the stringent Sullivan actual-malice rule. See Time, Inc. v. Firestone, 424 U.S. 418 (1976) (well-publicized divorce case of socialite not a "public controversy" sufficient to activate Sullivan rule); Gertz v. Robert Welch, Inc., 417 U.S. 323 (1974) (rejecting expansive definition of 'public figure' and giving states discretion to establish libel standards with fault standard as minimum); supra note 2 (citing cases).

A stronger reason for the unlikelihood of an absolute-protection rule for fiction derives from the form that discussion of the First Amendment has taken. In Sullivan, the "central meaning of the First Amendment" was said to have been "crystallized" by the "great controversy over the Sedition Act of 1798." New York Times Co. v. Sullivan, 376 U.S. 254, 273 (1964). Subsequent discussions of the free speech provisions of the First Amendment have often focused on their "political" dimensions, with some writers arguing that fiction is or is not entitled to protection depending on the expansiveness of their concept of "political." See BeVier, First Amendment Political Speech: An Inquiry into the Substance and Limits of Principle, 30 STAN. L. REV. 299, 355-58 (1978) (no First Amendment protection for fiction as political speech); Bork, Neutral Principles and Some First Amendment Problems, 47 IND. L.J. 1, 28 (1971) (same); Kalven, supra note 57, at 221 (Sullivan invites "dialectical progression" leading to Meiklejohn's conclusions); Meiklejohn, The First Amendment Is an Absolute, 1961 SUP. CT. REV. 245, 257 (literature included within politically relevant speech entitled to absolute protection). One need not exclude fiction altogether from the realm of political speech in order to acknowledge that it is less political than reportage dealing with the events and figures of actual politics. As long as the Court denies absolute protection for such reportage, a scheme providing greater protection for fiction would be anomalous. 


\section{B. "Clear and Convincing" Libel}

The crucial "of and concerning" element of a libel case involving fiction should be a test sufficiently rigorous to preserve a writer's First Amendment freedoms and protect him from liability in all cases but those in which plaintiff and character are, save for the libelous content, truly indistinguishable. That test should also be sufficiently specific to lead to predictable results and thus forestall a chilling effect on writers and publishers. A rigorous and specific "of and concerning" standard offers a means of ascertaining both whether readers might have taken a work of fiction as reportage and whether they were justified in doing so.

Sullivan and its progeny obliquely and coincidentally provide such a test. These cases require that proof of actual malice be "clear and convincing." "I7 In Sullivan, this requirement relates to the weight of the evidence presented. This Note proposes that libel cases involving fictional works demand that the evidence presented to meet the "of and concerning" requirement satisfy a three-part test aimed at establishing the clarity of the fictional work's reference to the plaintiff and the conviction this reference prompts in readers.

1. Clarity. The transparency with which a fictional character refers to a plaintiff should be central to any determination of libel. Only if the reference is clear does a purportedly fictional work fail to distinguish itself from reportage. ${ }^{78}$ But a substantive requirement of clarity, without further elaboration, seems vague and not readily distinguishable from the test of reasonable identification. The criterion can, however, be further particularized in the first two elements of a proposed three-part "of and concerning" test.

a. Unmistakability. In libel cases involving fiction, evidence of clarity should first of all be evidence of unmistakability: A character must be identifiable with the plaintiff and with no one else who does or could

77. New York Times Co. v. Sullivan, 376 U.S. 254, 285-86 (1964), requires that evidence presented to prove the "of and concerning" requirement have "convincing clarity." Subsequent cases have transmuted the standard to "clear and convincing proof." See Lorain Journal Co. v. Milkovich, 449 U.S. 966, 970 (1980) (Brennan, J., dissenting); Gertz v. Robert Welch, Inc., 418 U.S. 323, 342 (1974).

78. It is perhaps worth noting that courts have long considered the clarity of a threat posed by an exercise of free speech as a predicate to the abridgement of First Amendment rights. Clarity made its appearance in the Supreme Court's efforts to evolve a test for "clear and present danger," meant to distinguish protected advocacy of a cause from unprotected incitement to lawlessness. See Schenck v. United States, 249 U.S. 47, 52 (1919) (test is "whether the words used are used in such circumstances and are of such a nature as to create a clear and present danger that they will bring about the substantive evils that Congress has a right to prevent"). The Court's current test retains a part of the original standard in requiring that speech not be suppressed or punished unless "likely to incite or produce" imminent lawless action. Brandenburg v. Ohio, 395 U.S. 444, 447 (1969). On the development of the standard, see Strong, Fifty Years of "Clear and Present Danger": From Schenck to Brandenburg-and Beyond, 1969 SUP. CT. REV. 41. 
exist. When a character is not a composite, and not merely evocative of but identifiable with a single individual, the novelist has failed to regard the synecdochic dimension of fiction. Only in such a case should the plaintiff be permitted to prevail. ${ }^{79}$

A requirement of unmistakability protects authors who attempt to make their characters more representative by deriving them from multiple sources. As one court has observed, "suggestion is not identification."80 Readers familiar with a novelist's private circle, or encountering a work set in the sphere of public affairs, may find that one character "suggests" to them many people in real life. It seems fair to say that fiction embodies an economy of suggestion: To the extent one recognizes person $A$ in a character, one no longer recognizes person $B$, whose traits may have been drawn upon for part of the character but are distinguishable from those of person $A$. Unless we wish to allow multiple suits for libel over the same fictional character-which, given the roots of fiction in personal experience, might amount to a virtual prohibition of realistic fiction-we should insist that characters prompt no confusion in readers as to their real or potential sources. Any "of and concerning" standard short of unmistakability is, however, likely to encourage witnesses and juries to ignore such confusion.

b. Individuality. Evidence of clarity should also be evidence of individuality: The allegedly defamatory description must refer personally and specifically to the plaintiff, and not merely to a class or group of which he is a member. Because a novelist's medium is particular rather than general, concrete rather than abstract, he must anchor even observations intended generally in specific characters and incidents. ${ }^{81}$ When a novelist's targets are general-when he chooses, for example, to use his art to debunk a

79. Characters in literature can be seen as mixtures, in various proportions, of "representation" (an effort to reproduce a specific reality) and "illustration" (an effort to present selected aspects of the actual, which are referable for their meaning not to factual but to ethical or metaphysical truth). $R$. SCHOLES \& R. KELLOGG, THE NATURE OF NARRATIVE 84-88 (1966). While the novel leans toward the former pole, it is true that "[m]uch of the more interesting literary characterization can be seen as deriving from the instinct or desire of narrative artists to work on both sides of the gap." Id. at 89. It has also been argued that the representativeness of characters actually depends on their derivation from one of several literary "types": "All lifelike characters . . . owe their consistency to the appropriateness of the stock type which belongs to their dramatic function." N. FRYE, ANATOMY OF CRITICISM 172 (1957).

80. Wheeler v. Dell Publishing Co., 300 F.2d 372, 376 (7th Cir. 1962).

81. See Gugliemi v. Spelling-Goldberg Prods., 25 Cal. 3d 860, 869, 603 P.2d 454, 460, 160 Cal. Rptr. 352, 358 (1979) (Bird, C.J., concurring). In her concurrence, Chief Justice Bird states that

Contemporary events, symbols and people are regularly used in fictional works. Fiction writers may be able to more persuasively, or more accurately, express themselves by weaving into the tale persons or events familiar to their readers. The choice is theirs. No author should be forced into creating mythological worlds or characters wholly divorced from reality ..... Surely, the range of free expression would be meaningfully reduced if prominent persons in Id. the present and recent past were forbidden topics for the imaginations of authors of fiction. 
profession or pursuit-he should be accorded the same privilege as a political or social commentator inveighing against, say, politicians, lawyers, or football fans as a group without naming names. ${ }^{82}$

This second requirement might have forestalled the result in Bindrim $v$. Mitchell, in which the witnesses' identification of the plaintiff with the character appears to have occurred entirely at a general, professional level. The plaintiff and the character shared no physical characteristics or (to judge from the opinion) distinguishing personality traits. In fact, it was Mitchell's "substantially inaccurate description of what actually happened" at a therapy session and her casting of the plaintiff "in a disparaging light" that led to her liability. ${ }^{83}$ Insofar as such inaccuracies and disparagements are due to a work's efforts to discuss and describe (and

82. The individuality requirement must be reconciled with the problem of group libel. In Beauharnais v. Illinois, 343 U.S. 250 (1952), the Supreme Court affirmed a conviction under a state group-libel criminal statute. The Court accepted the then-prevailing view of libel as being outside the scope of First Amendment protection, a view since overruled by Sullivan. The potential scope of criminal libel statutes was restricted in Garrison v. Louisiana, 379 U.S. 64 (1964) (extending Sullivan rule to cases of criminal libel).

Whatever the availability of a criminal libel prosecution, group libel remains a viable civil action. A plaintiff, who may be any member of the allegedly defamed group, must establish that a libelous remark was directed at his "small group" and not at some indeterminate class. Church of Scientology v. Siegelman, 481 F. Supp. 866, 867 (S.D.N.Y. 1979); Neiman-Marcus v. Lait, 13 F.R.D. 311,315 (S.D.N.Y. 1952).

The proposals of this Note would leave no room for the application of group libel to works of fiction. This result is due to the peculiar nature of fiction as a concrete medium expressing also a general truth. In Arcand v. Evening Call Publishing Co., 567 F.2d 1163 (1st Cir. 1977), a defamatory charge against one unidentified member of a 21 -member police force did not give rise to an action by all 21 . The court suggested that allowing such an action would permit a suit by an entire baseball team over a report that one member was disciplined for brawling, a result which "would chill communication to the marrow." Id. at 1165.

The argument applies to fiction as well. Because fiction tends to deal in the particular and the personal, any "charge" it makes will likely be directed at a fictional individual, who under certain circumstances will be recognizable as a real person. This prototype will then have a valid libel claim. Allowing the "small group" of which he is a member also to sue for libel on the basis of the same fictional statement seems unduly harsh, especially when one remembers that the group claim has validity only after readers make an inductive leap (albeit invited by the synecdochic nature of fiction) from the particulars of fictional text to a general proposition about a group. The harshness of double vulnerability to libel, and the distance between a literal fictional statement maligning $A$ and the proposition derived therefrom that $A$ 's small group is worthy of scorn, together form a strong argument against fiction's liability for defamation of a group. An individual defamed by the literal statement of a fictional text retains his cause of action. Allowing his group a cause of action as well for a statement that only speculatively refers to it might indeed chill fictional expression to the marrow.

A student Comment appearing shortly before publication of this Note proposes the use of "group defamation analysis" as a first line of defense for writers of fiction accused of libel. Comment, Defamation by Fiction, 42 MD. L. REV. 387, 411 (1983). The author argues that the use of both "familiar archetypal characters" (such as "the domineering stage mothers" and "the spy in the trench coat") and "more mundane stereotypes" (such as "grandmothers" and "stewardesses") is a technique so common and unavoidable in fiction "that the reasonable reader is reluctant to rely on the use of these archetypal [characters] to satisfy the "of and concerning' requirement." Id. at 411-12. The arguments of the Comment and this Note, though differently expressed, are similar: The attributes of a fictional character that serve only to identify him with a group or class are not sufficiently "individual" to give rise to a libel claim.

83. 92 Cal. App. $3 d$ at 77,155 Cal. Rptr. at 38 . 
perhaps attack) a general undertaking, they cannot in themselves be said to defame an individual. Only when a work of fiction can be found to refer individually to this nude marathon therapist or this politician should recovery be permitted.

2. Conviction. Evidence in libel cases dealing with fiction should, additionally, prove conviction. It is not enough for the plaintiff to be identified with the character. Only when the immediate context of the allegedly defamatory statement convinces the reader of the statement's literal truth-when, that is, it ceases to be merely imaginable or plausible and begins to be believed-do damage to reputation, and thus liability, become possible.

This third requirement solves the problem of how to deal with unquestionably real characters used by novelists in hypothetical contexts. ${ }^{\mathbf{8 4}}$ Under the test proposed here, certain actions taken by otherwise identifiable fictional characters would not be libelous because they are incredible. Isidore Silver discusses Robert Coover's The Public Burning, a novel in which "Richard Nixon," who is one of the book's two narrators and has much in common with the political figure of the same name, engages in, inter alia, "a bungled would-be seduction of the imprisoned Ethel Rosenberg." W5 Whatever belief such an incident inspires can be said to be strictly symbolic; however "true" the statement, the reader presumably recognizes that its truth is not literal. At the same time, however, the implausibility of a particular fictional incident, or of a fictional story as a whole, should not altogether insulate a work from a libel claim. If isolated incidents, details, or actions in a fictional text are credible and otherwise satisfy the law of defamation, they can form the basis of a libel suit. ${ }^{86}$

84. See Silver, supra note 29, passim; cf. Comment, supra note 82, at 415-16 (proposing treatment of hypothetical fictional statements about real people as nondefamatory "opinion" or "rhetorical hyperbole").

85. Id. at 1067-69.

86. The "unit" of a fictional text capable of prompting conviction cannot be identified with any precision. There is nothing unusual in a critic's praising aspects of a novelist's portrayal as "known from the inside," F. LEAVIS, THE GREAT TRADITION 61 (1973), while deploring other aspects as not "real in any sense," id. at 79 (assessing George Eliot's Middlemarch). The law should be capable of a similar approach. If an unquestionably convincing (and otherwise defamatory) passage is embedded in a work of the rankest fantasy, the passage should be subject to a libel claim. The brevity of a section of a work is likely to affect the unmistakability and individuality of the characters it describes, for these will vary in proportion to the detail the writer provides. But just as criticism can judge brief sections of a work of fiction more or less plausible, so the law should be able to appraise the allegedly libelous "units" of a work of fiction as capable or not of convincing readers of their literal truth. The test should be whether the allegedly libelous section, viewed in but not controlled by its context, is convincing.

A recent decision of the Tenth Circuit applies a similar test in reversing a jury verdict for an allegedly defamed plaintiff. In Pring v. Penthouse International, Ltd., 695 F.2d 438 (10th Cir. 1982), cert. denied, 51 U.S.L.W. 3897 (U.S. June 21, 1983) (No. 82-1621), the court held that a magazine story describing sexual acts performed by an unnamed "Miss Wyoming" during the Miss America Pageant did not defame the real Miss Wyoming. "The test," said the court, is whether the allegedly 
In closer cases than the "Nixon" would-be seduction, the established law of libel becomes significant. Even when the "of and concerning" requirement is met, truth would remain a complete defense against a libel claim: If a "hypothetical" novel happens to have disclosed the truth, the novelist prevails. Because "public figures," who seem likeliest to be the subjects of speculative "fictionalizations," must prove that allegedy defamatory statements are false, ${ }^{87}$ such plaintiffs cannot recover merely because they prefer to keep details of their lives out of the public eye. If a plaintiff does prove that the truth differs from the allegedly libelous statement, a court can still conclude that the fictional material is "minor in offensiveness"s8 when viewed in light of undisputed facts. And if the plaintiff succeeds in showing that the fictional work varies from the facts in a defamatory fashion and consequently does harm to his reputation, then he can and should prevail. He has been injured by a work that, whatever labels or disclaimers it offers, presents itself not as fiction but as reportage.

\section{Conclusion}

This Note examines the present inconsistencies, irrelevancies, uncertainties, and dangers in the law of defamation when applied to works of fiction. It accordingly proposes a refinement of the "of and concerning" element of libel when applied to such works, permitting plaintiffs to recover only upon a showing that fictional characters refer to them unmistakably, individually, and convincingly. This proposal has the merit of stating clear standards that forestall a chilling effect on publishers and

defamatory "portions in context could be reasonably understood as describing actual facts about the plaintiff or actual events in which she participated." Id. at 442. The court's decision, however, ultimately rested upon its appraisal of these passages in isolation: "it is simply impossible to believe that a reader would not have understood that the charged portions were pure fantasy and nothing else. It is impossible to believe that anyone could understand that levitation could be accomplished by oral sex before a national television audience or anywhere else." Id. at 443.

Because the Pring court also observed that the story "was all fanciful and did not purport to be a factual account" and that the passages at issue presented "impossibility and fantasy within a fanciful story," it leaves open the possibility that the same "fanciful" passages might lead to liability in a more realistic context. The court also explicitly declined to consider the credibility of the acts described as part of the "of and concerning" requirement, and in fact accepted the jury's special verdict that the plaintiff and the fictional Miss Wyoming were identical. Id. at 440 . In other respects, though, Pring comports well with the proposals of this Note.

87. See New York Times Co. v. Sullivan, 376 U.S. 254 (1964). Sullivan itself contains no such specific requirement, but the Supreme Court has interpreted it that way: "We held in New York. Times that a public official might be allowed the civil remedy only if he establishes that the utterance was false and that it was made with knowledge of its falsity or in reckless disregard of whether it was false or true." Garrison v. Louisiana, 379 U.S. 64, 74 (1964).

88. Leopold v. Levin, 45 Ill. 2d 434, 443, 259 N.E.2d 250, 256 (1970) (holding in "false-light" privacy case that "fictionalized aspects" of book and film are "minor" when compared with known facts of plaintiff's infamous crime). Although this argument is an ad hoc one, its roots can be found in Sullivan, which speaks of the fear of self-censorship arising from "the difficulties of adducing legal proofs that the alleged libel was true in all its factual particulars." Sullivan, 376 U.S. at 279. Trivial falsehoods in a substantially correct account should not give rise to liability. 
writers. It dispenses with the misleading and often devastating Sullivan standard where it does not apply, while at the same time permitting what Sullivan intended to allow: a broader protection than the common law provides for works that fall within the sphere of the First Amendment. It suggests no radical or improbable changes in the present law, and in fact complements the requirements of that law. Finally, the standard allows recovery for deserving plaintiffs when they have actually been libeled by a work of fiction. 